\title{
Correlation of hyponatremia, leukocytosis, hypomagnesemia and fever after sah with delayed cerebral ischemia and poor outcome
}

\author{
V Vrsajkov ${ }^{1 *}$, N Mančić ${ }^{1}, M$ Galešev ${ }^{2}$, D Glišić ${ }^{1}$ \\ From ESICM LIVES 2015 \\ Berlin, Germany. 3-7 October 2015
}

\section{Introduction}

Early identification of patients at an increased risk for delayed cerebral ischemia (DCI) and poor outcome could allow more aggressive therapy and influence better outcome.

\section{Objectives}

The aim of this study was to determine a predictive association of hyponatremia, hypomagnesemia, fever and leukocytosis with DCI and poor outcome.

\section{Methods}

We prospective enrolled 68 patients with SAH treated from March 2011 to May 2013. Serum levels of sodium, magnesium and leukocyte count were determined at least once a day during the first 10 days after SAH. All patients underwent noncontrast $\mathrm{CT}$ scan $9 \pm 2$ days after SAH. DCI was defined as one or more of the next parameters: a new focal neurological deficit, decline for 2 or more points on the mGCS scale or a new hypodensity on CT scan. The outcome was assessed after 6 months using the eGOS scale.

\section{Results}

$48 \%$ of the patients recruited had delayed cerebral ischemia. Logistic regression model showed significant impact of hyponatremia $(\mathrm{p}=0,036 \mathrm{OR}=4.0895 \% \mathrm{CI}=1.09-15.26)$ on DCI and poor outcome $(\mathrm{p}=0,034 \mathrm{OR}=5.1195 \%$ $\mathrm{CI}=1.13-23.14)$. We obtained strong corelation of leukocytosis $(\mathrm{p}=0.013)$ with DCI and poor outcome $(\mathrm{p}=0,016)$. Association of non infectious fever and hypomagnesemia with DCI existed but wasn't significant enough.

${ }^{1}$ Clinical Centre of Vojvodina, Emergency Centre, Novi Sad, Serbia Full list of author information is available at the end of the article

\section{Conclusions}

Our results results confirmed association of hyponatremia and leukocytosis with greater risk of developing DCI and poor clinical outcome.

\section{Authors' details}

${ }^{1}$ Clinical Centre of Vojvodina, Emergency Centre, Novi Sad, Serbia. ${ }^{2} \mathrm{Clinical}$ Centre of Vojvodina, Clinic of Anesthesia and Intensive Therapy, Novi Sad, Serbia.

Published: 1 October 2015

\section{References}

1. Chandy D, Sy R, Aronow W, Lee W N, Maguire G, Murali R: Hyponatremia and cerebrovascular spasm in aneurysmal subarachnoid hemorrhage. Neurology Ind 2006, 54:273-275.

2. McMahon CJ, Hopkins S, Vail A, King AT, Smith D, Illingworth KJ, Clark S, Rothwell NJ, Tyrrell PJ: Inflammation as a predictor for delayed cerebral ischemia after aneurysmal subarachnoid haemorrhage. J Neurolntervent Surg 2013, 5(6):512-7, Nov.

doi:10.1186/2197-425X-3-S1-A783

Cite this article as: Vrsajkov et al:: Correlation of hyponatremia, leukocytosis, hypomagnesemia and fever after sah with delayed cerebral ischemia and poor outcome. Intensive Care Medicine Experimental 2015 3(Suppl 1):A783.

Submit your manuscript to a SpringerOpen ${ }^{\circ}$ journal and benefit from:

- Convenient online submission

- Rigorous peer review

- Immediate publication on acceptance

- Open access: articles freely available online

- High visibility within the field

Retaining the copyright to your article

Submit your next manuscript at $>$ springeropen.com (c) 2015 Vrsajkov et al.; This is an Open Access article distributed under the terms of the Creative Commons Attribution License (http:// creativecommons.org/licenses/by/4.0), which permits unrestricted use, distribution, and reproduction in any medium, provided the original work is properly cited. 